using the Mac's "Start up" program and by embedding a script into HyperCard's Home stack that goes to the desired card upon opening. Thus, the Call Number Directory stack is enacted merely by turning on the main power switch to the terminal. This is an important programming feature in an environment with many public terminals, each offering different files with different passwords and protocol. Similarly, the machine can be shut down at the click of a well-scripted button enabling Apple's ResCopy tool.

The familiar menubar at the top of the Macintosh screen is easily hidden through "openStack" scripting and, with no keyboard in use, essentially off-limits. Further, since the stack is "browsing" only in the public mode, and since a password is required before any modifications can occur, the stack is protected from tampering. The automated Call Number Directory - turned on in the morning and off in the evening-has an introductory screen that states its purpose and invites patrons to click away.

Simple scripts can be written that keep track of patron use by counting in invisible fields. Peak periods can be similarly identified by comparing these use statistics with the Mac's internal clock.

\section{Use}

Installed with no fanfare or announcement, the terminal has attracted attention-if for nothing other than curiosity. A Macintosh in an IBMdominated area demands attention despite its competitively small screen size and lack of color. The presence of even imperfect graphics compares favorably to the lack of same in the online and CDROM terminals. The Reference and Information Desk staffs have been gradually introducing patrons to the terminal's function-particularly when faced with the general question of "How do I find books by call number in this library?" Moreover, the program is now being introduced through the Center for Bibliographic Instruction-an of fice which administers BI to all new students through a required one-credit course- to familiarize a new generation of library users with the program.

In the meantime, however, some patrons prefer to bypass the system in favor of asking a quick question of a staff member. Despite an inherent "Short Cut" in the program (which allows users to skip some screens once comfortable with the system), some patrons simply are confounded by the number of questions that must be answered before finding out the correct floor or location. Indeed, the terminal is sometimes abandoned mid-stream. Although scripts are written to bring the program back to its introductory card after a certain amount of inactivity, programmers can make the "Payoff" of the location as exact as possible (down to the exact shelf) to keep the users' attention.

\section{Future}

In a multi-institutional database environment like WSU's online catalog, the HyperCard Call Number Directory could eventually be expanded to include all system-wide libraries' collections. Wayne State University Libraries are currently exploring the possibilities of adding features to the existing program: larger screen, color monitor, touch-screen response. Eventually, these features may evolve into an automated Information Kiosk that includes tours (with floor plans culled from the Call Number Directory), instruction (a required HyperCard BI program is in the final stages of development), and general campus information. Meanwhile, the HyperCard stack is a noticeably innovative alternative to an otherwise mundane transaction.

For further information about the HyperCard Call Number Directory, please contact: William P. Kane, Purdy Library, Wayne State University, Detroit, MI 48202; (313) 577-6439.

\title{
The academic reference librarian: Serving graduates in their job search
}

\author{
By Laura Windsor \\ Reference Librarian \\ Texas State Technical Institute
}

Academic reference librarians will encounter reference questions each quarter or semester from those students who are on the verge of graduating, or have already graduated. They can range from "Do you have any books on how to write a re- sume?" through "Who's hiring in the field of electronics?" to "Do you have some sort of list of companies in the import-export business?" Most of us will show them adequate reference sources, but our role in a student's quest for employment is 
many times seen as minimal, since most institutions have a placement office. Librarians may assume it is not their responsibility to assist job hunters other than pointing them toward the right source after being asked questions like those above.

I found myself taking on more responsibility in this area when a student nearing graduation in our Laser Electro-Optics Technology (LET), asked me if I would give a presentation to the Laser Club on the various reference sources useful to job hunters. I said I would be glad to but then realized I wasn't sure what other information they already had about job hunting, and whether they even knew we had a placement office on campus. I decided that before talking to them, I needed to get myself informed as to the functions of other campus units.

I discovered that it is of great benefit to students if the library is involved in the employment process, if not directly then at least indirectly. This can be accomplished by finding out what the placement office does and does not do for students who are job hunting. Services will vary greatly from institution to institution. Some placement offices will keep a file for the student with copies of letters of reference, an updated resume, certificates of awards and accomplishments, etc.; and upon a student's request send material out to prospective employers. Others may only post job announcements received in the mail and leave the rest up to the students.

In my case, I was surprised to find out that the Placement Office at Texas State Technical Institute does not function like a traditional one. I called to ask since: 1) I wanted to give a good presentation to the Laser Club; and 2) I was becoming overwhelmed with questions about company addresses, interviewing, resume and cover letter writing from other students as well. I had already decided to compile an annotated bibliography to aid job seekers as well as the library staff in responding to this type of need, and knew it would be beneficial to be able to give students information about the Placement Office.

I found out that the Placement Office here only provides placement for part-time work study students on campus. When I asked what graduating students were supposed to do they informed me that each program on campus is responsible for assisting those students in their area. Each program designates an instructor as a placement officer who is responsible for assisting students in their program to find jobs.

After speaking with a few program chairs, I found out that they usually send out a packet of information to prospective graduates about two quarters before graduation. Included is information on how to write resumes, whom to contact in the department for information on job availability and advice, and what upcoming events would be good for them to get involved in-job fairs, etc. Most instructors make themselves available to get students moving in the right direction. Once I had this information I was more confident about giving a presentation to the Laser Club.

During the presentation one thing I emphasized was to check with their program instructors and not hesitate to ask for assistance. They are more in touch with current industry needs and can steer students in the right direction. The annotated bibliography listed general reference directories useful in locating information on specific companies, or on companies in specific industries. Of course, many students are limited to one geographic area. I found myself answering lots of questions on what people should do if they are limited to where they would move because: 1) they want to stay close to home; 2) their spouse already has a steady job in a certain area; 3 ) they need a job near the institution where they want to continue their education; or 4) various other reasons.

For those students I gave the following advice which some felt was beneficial.

- If you are limited to a particular area you can use the telephone directory yellow pages for that area. Most libraries have telephone directories for many cities either on microfiche or in paper copy. If not, the librarian can probably tell you where in the area this would be available. Look up appropriate subjects and obtain the names of companies in the area that would be likely to employ people in your discipline. Phone numbers as well as a street address will be given. You can then look in a zip code directory for the zip code in order to request an application, send a letter of application and resume, or just call to inquire about job openings.

-Use the Gale Directory of Publications to get the address of the largest newspaper in the area you are interested in. Then, even if your library doesn't subscribe to it, you can write and request a Sunday paper. Include enough money to cover the cost of the paper. Some larger newspapers will even give a free trial subscription to prospective residents of the area.

The other items I listed on the bibliography were specific to TSTI,

- Check the "Current Job Openings" section near the reference area. In this section of the library we keep publications like the Career Opportunity Update, the Federal Jobs Digest, the $\mathrm{Na}$ tional Employment Opportunities Newsletter, and other publications with job listings or job information. We feel the publications are used more since they are all in the same area rather than kept with the rest of the periodical collection.

- Check the TSTI Periodicals by Technology List. This list was compiled by the periodicals librarian; beneath the name of each technology program on campus is a list of the periodicals we have that pertain to that particular program. Most of the students are already familiar with this list but I reiterated it since job leads can often be found in the classified sections of these periodicals.

- Check the Employers of TSTI Graduates. This is a listing by technology program of current em- 
ployers of TSTI graduates. The library solicits the information from each program and tries to update it each year by contacting the various programs for the information. It is helpful in letting students see where former graduates of their technology program are now working. The list varies in quality and is mainly dependent on the effort of each program to supply the information to us. Of course, the student can also gain this information from his or her program, but it has proved convenient to have this compilation at the library also.

Overall, I think the presentation to the Laser Club went very well. I could tell they were grateful someone took the time to talk to them because so many of them asked questions and commented on how they really appreciated my time. I'm looking forward to giving this type of presentation more often. Students or faculty do not usually request such a service, but it is obviously needed. The success and extent of this service rests with the librarian. I feel it is worthwhile because after all, when we give library instruction classes one of our goals is for the student to view the library as an information place-not just a study hall during their years of college, but as a resource place anytime, now and in the future. And what better way to solidify this concept than helping them pursue a career? Lifelong learning exemplified!

\title{
Science collections in
}

\section{community college libraries}

\author{
By Kate Bradley \\ Acquisitions Librarian \\ Bellevue Community College, Washington
}

\section{Using the conspectus to assess curriculum support.}

\begin{abstract}
A s a community college library in the Pacific Northwest we had an opportunity to participate in the Library and Information Resources for the Northwest (LIRN) regional assessment project. Because of staff turnover at the time, Bellevue Community College did not become involved in the initial stages of LIRN. Early reports from other community college libraries performing the LIRN assessment did not encourage belated participation.

For community colleges the main advantage of doing the assessment was that librarians gained hands-on familiarity with their collections, becoming aware in many instances that major portions of
\end{abstract}

the library were badly outdated, requiring extensive weeding and replacement. The deficiency of the LIRN project has to do with the nature of community colleges in Washington state and the relationship of the libraries to the colleges.

As education costs rise and acceptance into the state universities becomes increasingly competitive, the function of community colleges has gradually shifted from two-year vocational/technical training to undergraduate preparation for transfer to four-year institutions. In the spring of 1988 , “among bachelor's degree recipients at public regional institutions, about $48 \%$ were students who transferred credits from a Washington community 